\title{
REMOTELY SENSED WINDS AND WIND STRESSES FOR MARINE FORECASTING AND OCEAN MODELING
}

\author{
Mark A. Bourassa ${ }^{(1)}$, Ad Stoffelen ${ }^{(2)}$, Hans Bonekamp ${ }^{(3)}$, Paul Chang ${ }^{(4)}$, D. B. Chelton ${ }^{(5)}$, Joe Courtney ${ }^{(6)}$, \\ Roger Edson $^{(7)}$, Julia Figa ${ }^{(8)}$, Yijun He ${ }^{(9)}$, Hans Hersbach ${ }^{(10)}$, Kyle Hilburn ${ }^{(11)}$, Zorana Jelenak ${ }^{(4)}$, \\ Kathryn A. Kelly ${ }^{(12)}$, Richard Knabb ${ }^{(13)}$, Tong Lee ${ }^{(14)}$, Eric J. Lindstrom ${ }^{(15)}$, W. Timothy Liu ${ }^{(14)}$, \\ David G. Long ${ }^{(16)}$, William Perrie ${ }^{(17)}$, Marcos Portabella ${ }^{(18)}$, Mark Powell $^{(19)}$, Ernesto Rodriguez ${ }^{(14)}$, \\ Deborah K. Smith $^{(11)}$, Val Swail ${ }^{(20)}$, and Frank J. Wentz ${ }^{(11)}$
}

(1) Center for Ocean-Atmospheric Prediction Studies, and Department of Meteorology, Florida State University, 2035 E. Paul Dirac Dr., 200 RM Johnson Bldg., Tallahassee, FL 32306-2840 USA, Email: bourassa@coaps.fsu.edu

${ }^{(2)}$ KNMI (Koninklijk Nederlands Meteorologisch Instituut), Postbus 201, 3730 AE De Bilt, The Netherlands, Email: Ad.Stoffelen@knmi.nl

(3) EUMETSAT (European Organisation for the Exploitation of Meteorological Satellites), Eumetsat Allee 1, D-64295 Darmstadt, Germany, Email: hans.bonekamp@eumetsat.int

${ }^{(4)}$ NOAA/NESDIS (National Oceanic and Atmospheric Administration/National Environmental Satellite, Data, and Information Service)/Center for Satellite Applications and Research, NOAA Science Center, Room 105, 5200 Auth Road, Camp Springs, MD 20746 USA,Email: paul.s.chang@noaa.gov; zorana.jelenak@noaa.gov

${ }^{(5)}$ College of Oceanic and Atmospheric Sciences, 104 COAS Administration Building, Oregon State University, Corvallis, OR 97331-5503 USA, Email: chelton@coas.oregonstate.edu

(6) Bureau of Meteorology, PO Box 1370, West Perth, WA 6872 Australia, Email: J.Courtney@bom.gov.au

(7) NOAA/NWS (National Oceanic and Atmospheric Administration/National Weather Service), 3232 Hueneme Road, Barrigada, Guam 96913 USA, Email: roger.edson@ noaa.gov

${ }^{(8)}$ EUMETSAT (European Organisation for the Exploitation of Meteorological Satellites), Eumetsat Allee 1, D-64295 Darmstadt, Germany, Email: Julia.Figa@eumetsat.int

${ }^{(9)}$ Key Laboratory of Ocean Circulation and waves, Institute of Oceanology, Chinese Academy of Sciences, 7 Nanhai road, Qingdao 266071, Shandong Province, P. R. China, Email: heyj@ms.adio.ac.cn

(10) European Centre for Medium-Range Weather Forecasts, Shinfield Park, RG2 9AX, Reading, United Kingdom, Email: Hans.Hersbach@ecmwf.int

${ }^{(11)}$ Remote Sensing Systems, 438 First St., Santa Rosa, CA 95401 USA, Email: hilburn@remss.com; smith@remss.com; frank.wentz@remss.com

${ }^{(12)}$ Applied Physics Laboratory, University of Washington, 1013 NE 40th St, Seattle, Box 355640, Seattle, WA $98195-$ 5640 USA, Email: kkelly@apl.washington.edu

${ }^{(13)}$ NOAA/NWS/PR (National Oceanic and Atmospheric Administration/National Weather Service/Pacific Region), Honolulu Forecast Office, 2525 Correa Rd., Ste 250, Honolulu, HI 96822 USA, Email: richard.knabb@noaa.gov

(14) NASA (National Aeronautics and Space Administration) Jet Propulsion Laboratory, California Institute of

Technology, 4800 Oak Grove Dr., Pasadena, CA 91109 USA, Email: tong.lee@jpl.nasa.gov; w.t.liu@jpl.nasa.gov; ernesto.rodriguez@jpl.nasa.gov

${ }^{(15)}$ NASA (National Aeronautics and Space Administration Headquarters, Earth Science Division, Room 3D74, Science Mission Directorate, NASA Headquarters, Mail Suite 3B74, 300 E Street SW, Washington DC 20546 USA, Email: eric.j.lindstrom@nasa.gov

${ }^{(16)}$ Brigham Young University, 459 Clyde Building, Provo, Utah 84602 USA, Email: long@ee.byu.edu

${ }^{(17)}$ Fisheries and Oceans Canada, Bedford Institute of Oceanography, 1 Challenger Drive, P.O. Box 1006, Dartmouth, Nova Scotia, B2Y 4A2 Canada, Email: William.Perrie@dfo-mpo.gc.ca

${ }^{(18)}$ Unidad de Tecnologia Marina (UTM - CSIC (Marine Technology Unit - Consejo Superior de Investigaciones Científicas/Spanish National Research Council)), Pg. Maritim de la Barceloneta 37-49, 08003 Barcelona, Spain, Email: portabella@cmima.csic.es

${ }^{(19)}$ NOAA(National Oceanic and Atmospheric Administration) Atlantic Oceanographic and Meteorological Laboratories, Hurricane Research Division, Center for Ocean-Atmospheric Prediction Studies, Florida State University, 2035 E. Paul Dirac Drive, Tallahassee, FL 32310 USA, Email: mark.powell@noaa.gov

${ }^{(20)}$ Environment Canada, 4905 Dufferin Street. Toronto, Ontario, Canada M3H 5T4, Email: Val.Swail@ec.gc.ca

\section{INTRODUCTION AND MOTIVATION}

Ocean surface vector winds (OSVW) are used to estimate momentum transfer (surface stress) between the atmosphere and ocean, and are critically important for determining the large-scale ocean circulation and transport. Vector winds are needed to estimate the ageostrophic (Ekman) component of ocean currents, and consequently are linked to atmospheric and oceanographic upwelling and downwelling, coastal upwelling, primary productivity, cross shelf transport, 
ice transport, mixed layer evolution, and deep-water formation. Accurate wind speeds are also essential for reliable computations of air/sea heat fluxes (e.g. sensible and latent heat fluxes) as well as mass fluxes (e.g. $\mathrm{CO}_{2}$ and $\mathrm{H}_{2} \mathrm{O}$ ), making surface winds critically important for budgeting energy, moisture and Carbon, and for studies of ocean acidification. Wind and wave information are essential for marine safety.

The advection and offshore transport of nutrients and fresh water can be linked to the life cycle and annual variability in fish stocks. Both scalar and vector winds can be linked to upper ocean mixing, which is easily linked to ocean, atmospheric, cryospheric and terrestrial climate change. For shorter time scale applications, surface wind vectors are also used for forecasts of storm surge and waves.

Ocean surface winds change rapidly in both time and space. Satellite-based sampling density and relatively good accuracy make satellite winds desirable data (particularly for regions with sparse in situ observations) for many related applications such as coastal upwelling, oceanic/atmospheric coupling associated with both tropical instability wave and ocean fronts [19], ocean currents [58], detection of tropical disturbances [35], wave forecasting, weather forecasting [46], and storm surge [79], to list a small sample of applications. Portions of the surface winds observing systems are also used to provide observations of sea ice extent and rainfall (fresh water flux).

Several reviews of space-based wind measurements and applications have been published (e.g. [64 and 66]). The current ocean wind observing system can be further improved by means of better bias removal and calibration for very high and low wind speeds, increased temporal sampling (via a constellation), finer spatial resolution (e.g. on the ocean eddy scale and intercalibration of near-coastal winds), and improved methods of blending observations (scalar winds and vector winds) from multiple platforms.

\section{DEFINITION OF SATELLITE WINDS}

Satellite-derived wind speed (called equivalent neutral wind speed [94 and 65] was developed to consider the influences of atmospheric stability in the conversion from 'winds' to stress. It has the advantage of determining a wind speed for which a neutral transfer coefficient can be used to convert the satellites' equivalent neutral winds to a kinematic stress. An updated definition of equivalent neutral winds [12] is consistent with scatterometry, which responds to surface stress [111]. It is also considered to be applicable to SAR (Synthetic Aperture Radar) [107] and SSM/I (Special Sensor Microwave/Imager) [74] derived wind speeds. Unfortunately, accurate measurements of nearsurface stress over water are extremely sparse relative to wind speed; therefore, winds have been calibrated to equivalent neutral winds rather than wind stress [111 and 88].

Another issue to consider is that scatterometer equivalent neutral winds are relative to currents $[56,21$ and 19] and are further modified by surface wave motion [10]. In the calculation of air/sea turbulent fluxes, currents and the effect of wave motion should be removed from earth relative winds (e.g. [53]), which gives satellite observations a considerable advantage over in situ (earth relative) observations. Improvements in our understanding of remotely sensed winds made in the last decade are expected to improve ocean forcing in the next decade.

\section{WIND SENSORS}

Instruments that are routinely used to measure vector winds (speed and direction or two vector components) will be discussed first, followed by instruments that are typically used to measure scalar winds (speed only). Vector winds are useful for a wider range of applications, but both are quite useful for many applications. The observational needs are most consistent with scatterometers, particularly DFS (DualFrequency Scatterometer) or XOVWM (Extended Ocean Vector Wind Mission) (Sect. 5); however, SAR is more capable very close to land and where very fine resolution is required. Currently data are freely available from USA satellites, ERS-2 (European Remote-Sensing Satellite) and ASCAT (Advanced Scatterometer) on the MetOp satellite.

\subsection{Vector Wind Sensors}

\subsubsection{Scatterometers}

There is a long history of scatterometer observations, which are based on active microwave systems: SeaSat [51], ERS1 and ERS2 [8], NSCAT (NASA's (National Aeronautics and Space Administration) Scatterometer) [81, 106 and 115], SeaWinds on QuikSCAT (Quick Scatterometer Satellite) [103], SeaWinds on ADEOS2 (Advanced Earth Observation Satellite), and ASCAT [30]. These instruments provide very accurate winds in rain-free conditions and in some raining conditions [24, 25, 112 and 82]. They have in-swath grid spacing on scales of typically $25 \mathrm{~km}$, with special products $[71,117$, 118 and 85] having grid spacing as fine as $2.5 \mathrm{~km}$ (Fig. 1). The temporal sampling is a function of the orbit and the swath width, with the SeaWinds instruments having very good sampling for synoptic scale weather forcing of the ocean, with substantial information on the mesoscale. The main weaknesses of scatterometers are rain contamination for some rain conditions (far more so for Ku-band than C-band), a lack of data near land $(15 \mathrm{~km}$ for QuikSCAT; $30 \mathrm{~km}$ for ASCAT), and temporal sampling. Multiple scatterometers greatly improve the temporal sampling 


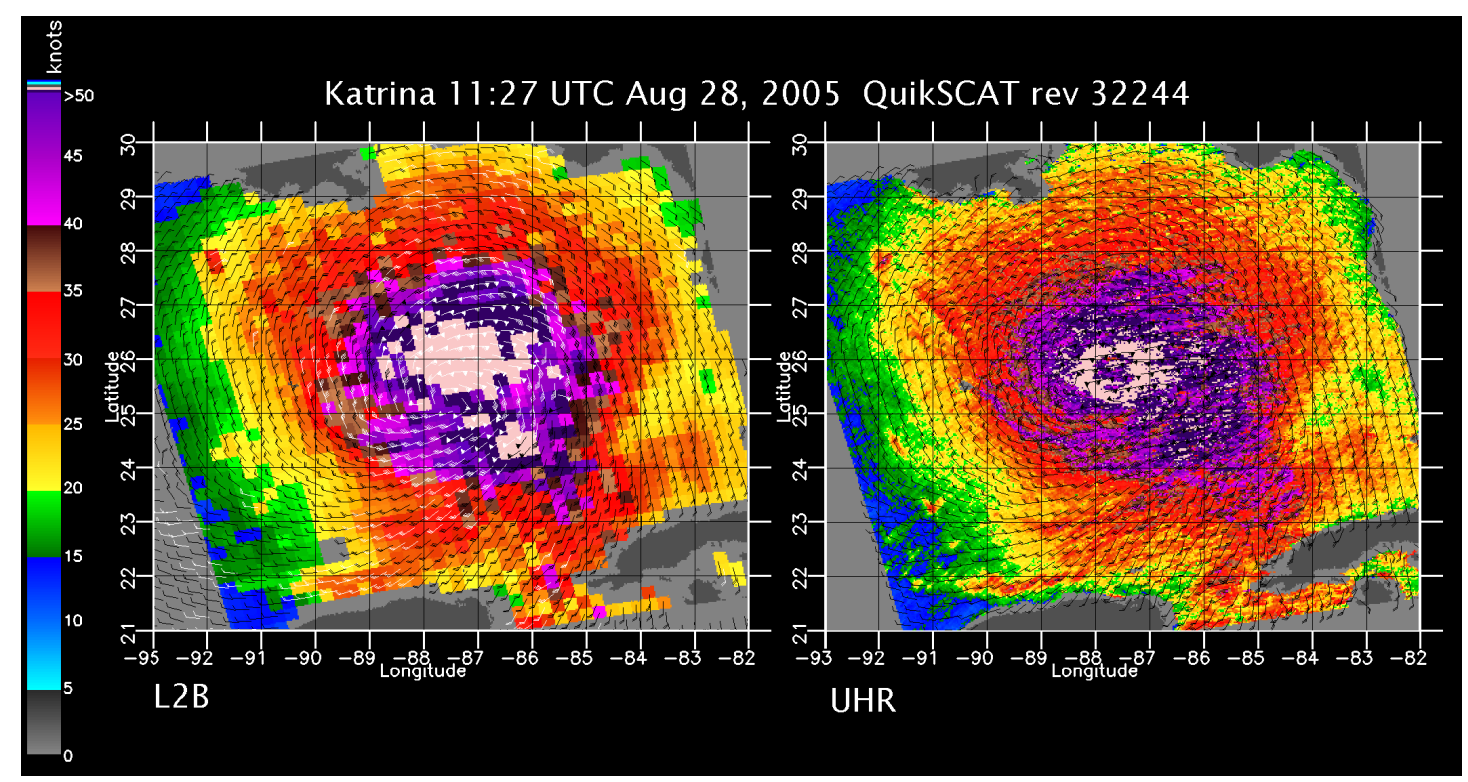

Figure 1. Higher resolution scatterometer product. An algorithm for ultra high-resolution retrieval of vector winds over the ocean from QuikSCAT data has been developed [72]. In this approach, ultra high-resolution (2.5 km/pixel) backscatter images are created for each look direction. Then, for each wind vector pixel, a conventional wind retrieval algorithm is employed to produce ultra high-resolution wind estimates posted at $2.5 \mathrm{~km} /$ pixel resolution. This algorithm is running in near-real time for 'postage stamp' invest areas at NOAA (http://manati.orbit.nesdis.noaa.gov/cgi-bin/qscat_storm.pl see BYU hiRes links). Note that the ultra high resolution image (right) shows an eye and eyewall, whereas these are blurred together in the $25 \mathrm{~km}$ resolution image (left).

[70]. The key advantages are more data in rainy conditions and much better directions.

\subsubsection{Passive Polarimetric Sensors}

WindSat, launched in January 2003, is the sole instrument using passive polarimetric techniques for estimating ocean surface vector winds [33]. Although in clear skies and winds in the range of $6 \mathrm{~m} / \mathrm{s}$ to $20 \mathrm{~m} / \mathrm{s}$, WindSat OSVW (Ocean Surface Vector Winds) are of comparable quality to scatterometry [9], an NRC (National Research Council) Workshop Report "Options to Ensure Climate Record from NPOESS (National Polar-orbiting Operational Environmental Satellite System) and GOES-R (Geostationary Operational Environmental Satellite R-Series)" concludes that there is significantly larger wind direction uncertainty in WindSat retrievals at typical wind speeds [32]. Furthermore, different versions of WindSat wind speeds can be biased either high [3 and 91] or low in high wind speed conditions such as tropical or extratropical cyclones. WindSat wind vector retrievals are much more susceptible to error in cloudy and rainy conditions, which are often associated with extreme weather events. This susceptibility affects the use of WindSat OSVW forecast systems for wind warnings and for the development of accurate climatologies of such events [14]. However, new rain algorithms are available to improve WindSat winds [75], providing similar quality to QuikSCAT in all but very heavy rain and very low winds. Measurements are also more subject to contamination by land in the antenna sidelobes. Consequently, WindSat measurements are not possible closer than 50 to $75 \mathrm{~km}$ off the coast, depending on what channels are used.

\subsubsection{Synthetic Aperture Radar (SAR)}

C-band and L-band SAR systems have been used to retrieve surface winds on ERS1, ERS2, Envisat (Environmental Satellite), RADARSAT1, ALOS (Advanced Land Observation Satellite), and RADARSAT2. Also, X-band SAR algorithms are being developed to retrieve winds on COSMO-SkyMed (COnstellation of small Satellites for the Mediterranean basin Observation) and TerraSAR-X. SAR has the advantage of being able to generate images on a much finer spatial scale (as small as $<10 \mathrm{~m}$ ). Reference [107] calibrated RADARSAT1 images, with a wind retrieval model function relating wind speed to the normalized radar cross section, relative wind direction and local incidence angle, motivated by scatterometry. However, the directional dependence of SAR-derived vector winds is much less certain than for scatterometers. Since there are at least two geophysical parameters (wind speed and direction) modulating SAR measurements, the inversion of winds from SAR data is inherently underdetermined. Some wind direction information can be estimated by measuring the orientation of the 
wind-induced streaks visible in most SAR images [110 and 43]. Many retrieval studies with both VV (Vertical transmit - Vertical receive polarization) and HH (Horizontal Transmit - Horizontal Receive Polarization) polarization SAR have been carried out [107, 42 and 83].

\subsection{Scalar Wind Sensors}

Surface wind speeds (at $10 \mathrm{~m}$ height, without directions) are routinely estimated from passive microwave radiometers (SSM/I, AMSR-E (Advanced Microwave Scanning Radiometer for EOS (Earth Observing
System), TMI (TRMM (Tropical Rainfall Measuring Mission) Microwave Imager), SSMIS (Special Sensor Microwave Imager/Sounder)) on a spatial scale of roughly $25 \mathrm{~km}$. These instruments are quite accurate (rms differences $<1 \mathrm{~m} / \mathrm{s}$ relative to buoys) under typical ocean conditions [74 and 76], but do not retrieve winds in rain [40]. Excellent agreement is found between passive radiometer winds and vector winds from scatterometers despite different measuring methods [116], with the exception of a few small regions of bias. Since 1996, there have been three or more radiometers in polar orbits resulting in good spatial and temporal

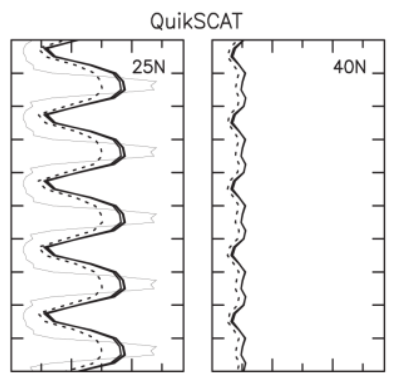

QuikScat/SeaWinds
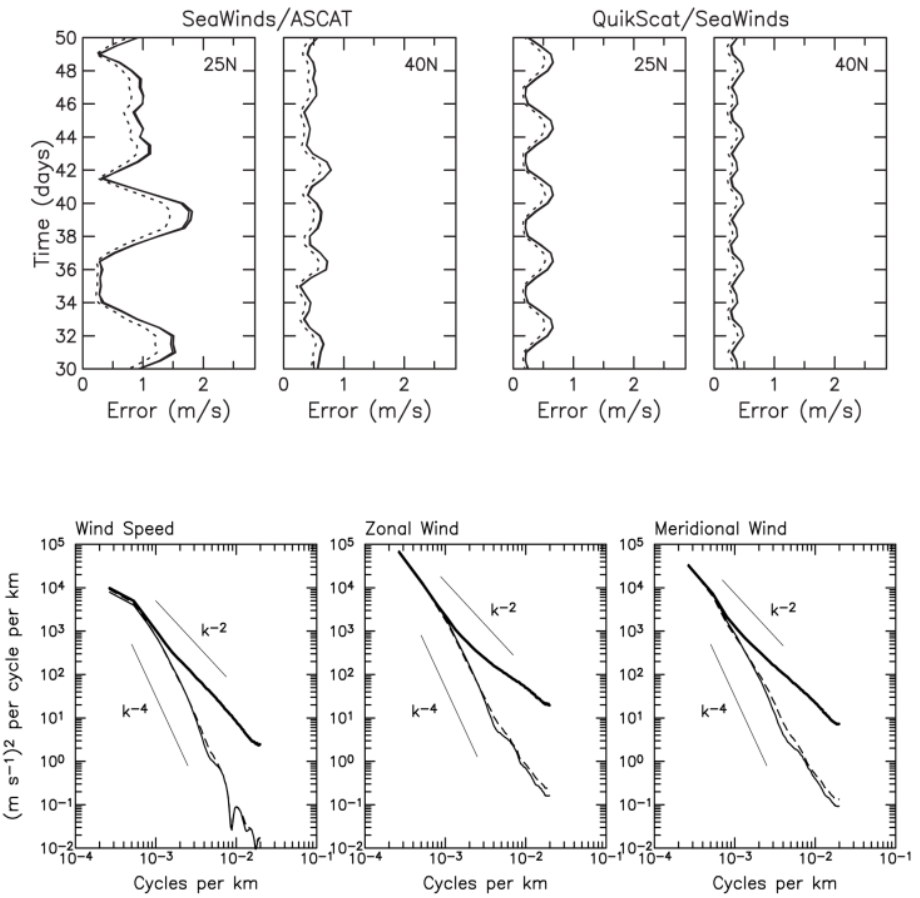

Figure 2. Upper panels: Time series of the RMS mapping errors of meridional (solid lines) and zonal (dotted lines) wind estimates constructed at latitudes of $25^{\circ} \mathrm{N}$ and $40^{\circ} \mathrm{N}$ from various combinations of scatterometer observations with $2^{\circ}$ by $2^{\circ}$ by 4 -day smoothing. The three solid lines correspond to different assumed forms for the spatial autocorrelation function. The small differences show that the results are not strongly sensitive to the details of the spatial autocorrelation function; the most limiting factor for construction of wind fields is the short decorrelation time scale of the surface wind field. (The thin solid line in the QuikSCAT panel is a time series of the RMS (Root-Mean-

Square) mapping errors at $25^{\circ} \mathrm{N}$ with $2^{\circ}$ by $2^{\circ}$ by 1.5-day smoothing.) (From [97].) Lower panels: Along-track wavenumber spectra of wind speed and the zonal and meridional wind components in the eastern North Pacific, accumulated over 2004, computed from QuikSCAT observations (heavy solid lines), NCEP (National Centers for Environmental Prediction ) analyses (thin solid lines) and ECMWF analyses (dashed lines; the 2004 version had $\sim 40 \mathrm{~km}$ grid spacing compared to the current $\sim 25 \mathrm{~km}$ ). Note the drop-off of spectral energy in the two operational forecast models at wavelengths shorter than about $1000 \mathrm{~km}$ (wavenumbers higher than about $10^{-3} \mathrm{cycles} \mathrm{per} \mathrm{km}$ ).

(From [20].) 
sampling, covering 95\% of Earth's ocean surface in a given day [125]. Combined surface wind data sets are available online from several sources [4, 7 and 125].

Altimeters can also accurately estimate wind speed on a smaller spatial scale. However, the sampling from current altimeters is very sparse.

\subsection{Sampling Issues in Scatterometer Observations of Surface Winds}

Scatterometers measure surface winds with a resolution of $\sim 25 \mathrm{~km}$ across a swath width of $\sim 1000 \mathrm{~km}$. A given location is typically sampled less than twice per day by a single scatterometer. Because of the rapid evolution of weather systems, wind fields constructed from scatterometer measurements can be quite noisy without sufficient spatial and temporal smoothing [97]. The sampling errors for a given amount of smoothing vary temporally and geographically in complicated ways (see upper panels of Fig. 2).

As shown from the wavenumber spectra in the lower panels of Fig. 2, present operational global weather forecast models are not able to resolve the $\sim 25 \mathrm{~km}$ scales measured by scatterometers (e.g. [20]). The models can potentially benefit greatly from assimilation of scatterometer winds; however, practical limitations within assimilation schemes complicate the ingestion of small-scale information. Such assimilation is subject to the same sampling issues, which must be mitigated by down-weighting the scatterometer observations. The benefits of a constellation of scatterometers are evident from the smaller sampling errors shown in the middle row of panels of Fig. 2.

\section{PROGRESS IN OPERATIONAL EXPLOITATION}

The primary operational benefits of satellite OSVW observations are the improvements of weather forecasting and warnings. In addition, knowledge of the winds and waves over the ocean is also essential for the maritime transportation, fishing, and oil production industries, as well as for search and rescue efforts, and the accurate tracking and management of marine hazards such as oil spills. It is also essential for determining the ocean forcing, wind induced mixing, currents [58], and air/sea $\mathrm{CO}_{2}$ fluxes.

\subsection{Impact on NWP Winds}

The assimilation of ERS1/2 scatterometer winds was reported to dramatically improve the forecasts of tropical cyclones [46] and has been operationally implemented at ECMWF (European Centre for Medium-Range Weather Forecasts) since the mid-1990s [47]. Many operational weather centers began assimilating QuikSCAT data in early 2002, with preliminary assessments indicating a positive impact [5]. The improvements were larger in the storm track regions, where there is relatively large and rapid variability in the winds [16 and 48]. The assimilation of satellite data is particularly important in the southern hemisphere, where much fewer in situ surface data are available [41]. Wind speeds from passive radiometers have been operationally assimilated for a longer time period; and could benefit from improved sampling (see Sect. 2.3) in time. However, the vector information from scatterometers has a greater impact for data assimilation [2]. Regardless of these beneficial effects in NWP (Numerical Weather Prediction), current NWP analyses do not contain the mesoscale structures on the ocean eddy scale as determined by scatterometers (e.g. see Sect. 4.5).

\subsection{Impact of Satellite Winds on Wave Model Development, Applications and Forecasting}

The assimilation of scatterometer data into NWPs in major forecast offices has improved skill in wave forecasting as well as the development of long-term wave climatologies and extreme wave design criteria (e.g. [22]). Optimum utilization of satellite winds requires: (1) establishment of the accuracy and full dynamic range of the data and (2) the development of efficient methods that combine satellite and in situ winds into high-resolution time and space forcing fields [92]. With few exceptions (e.g. SWADE (Surface Wave Dynamics Experiment) IOP-1 (Intensive Observation Period); [16]) errors in marine surface wind fields developed from conventional data remain sufficiently large to mask errors arising from uncertainties in the physics of wave models, thereby inhibiting further progress. Satellite winds offer a potent solution to the need for reference quality forcing fields and improved wave hindcasts and forecasts. While satellite estimates of surface marine winds have long been available, it was not until the assimilation of QuikSCAT's Ku-band wide-swath scatterometer data that a truly global, accurate and reasonably long-term record of marine vector winds was achieved.

SAR offers the potential of very fine resolution winds which is important in situations involving mesoscale features such as the eyes of hurricanes [86]. In addition to the limitations noted in Sect. 2.2.3, data availability remains a problem; RADARSAT- 1 and RADARSAT-2 data are available for limited users and TerraSAR-X is a commercial platform, also with limited data access for scientific use.

\subsection{Impact on Surge Forecasting}

Knowledge of the current and past wind (or stress) fields is essential for surge forecasting [105]. The winds used in surge models are forecast winds, which are greatly improved by observations from the recent past and the environment about the storm. Assimilation of observed winds improves the quality of the storm size and position of the model forecast. Furthermore, winds 
from the recent past can be very important for surge due to non-local processes [79].

\subsection{Marine Nowcasting}

Satellite wind data are used in the daily operations of all NOAA/NWS National Oceanic and Atmospheric Administration/National Weather Service) offices with marine warning and forecasting responsibilities. Ocean surface winds were derived from the passive SSM/I data since the early 1990s [113 and 114], but with less resolution and wind intensity range than the QuikSCAT data. Satellite winds are routinely used to modify NWP output related to severe weather [109, 63 and 18], with great positive impacts. Since QuikSCAT, winds have been available in near real-time on analysts' workstations, the number of short-term wind warnings issued by NOAA/OPC (Ocean Prediction Center) forecasters for the mid-latitude high seas waters have dramatically increased. In particular, hurricane force warnings were not issued for extratropical regions prior to QuikSCAT observations [109]. ASCAT winds in the North Atlantic are now made available within 30 minutes after sensing to aid nowcasting applications. However, ASCAT's lesser coverage (coverage is problematic for a single wide swath scatterometer such as QuikSCAT) and calibration to lower wind speeds where QuikSCAT reports hurricane force winds in extratropical storms is a problem for nowcasting.

\subsection{Tropical Cyclone Forecasting}

The usefulness of satellite winds in forecasting varies with regional differences in the availability of other types of observations (particularly aircraft reconnaissance) and regional practices [16]. The use of a satellite-based active microwave scatterometer, with QuikSCAT-like sampling is considered (in some forecast offices) essential to the analysis and understanding of the near ocean surface wind field
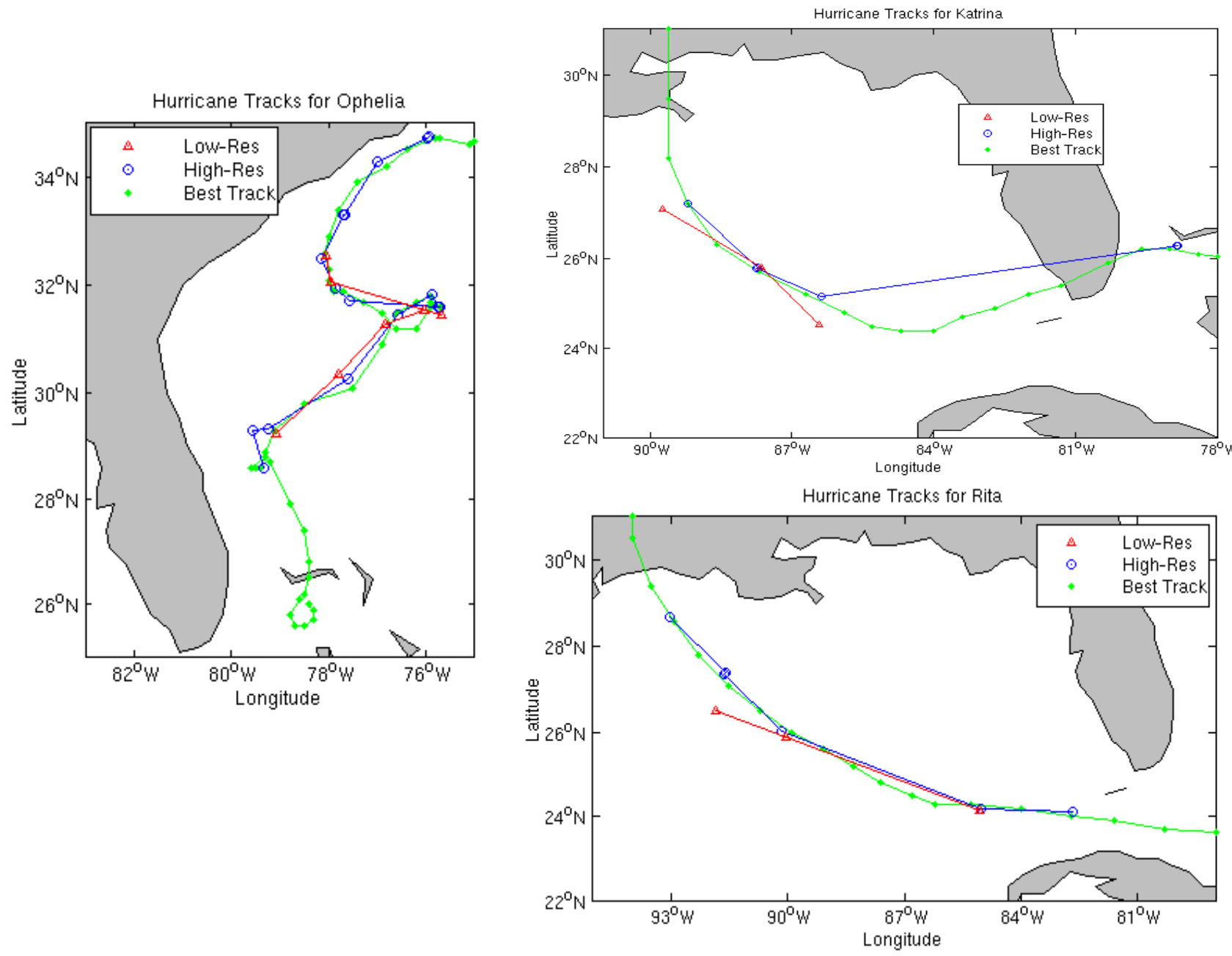

Figure 3. Comparison of hurricane locations derived from conventional and ultra high-resolution QuikSCAT data with "best track" positions for Ophelia, Katrina, and Rita from the 2005 hurricane season. Each red or blue point represents one pass of QuikSCAT over the storm. For some passes, a circulation center cannot be determined from conventional resolution QuikSCAT due to land proximity. Note that the derived high-resolution positions almost always correspond to the best track positions [39]. 
about tropical cyclones (TCs). Near real-time knowledge of both wind speed and direction offers the regional tropical cyclone forecaster the ability to more accurately anticipate TC genesis, see the development of the inner and outer core winds or structure, and determine a 'minimum estimate' for a TC's maximum sustained winds. This, in turn, provides a fundamental basis for improving TC forecasts and providing more timely and efficient warnings to the public.

Active sensors are favored due to the ability to retrieve winds through some rain. QuikSCAT observations have been found to be crucial in the evaluation of developing tropical systems. Accurate knowledge of the wind field around the tropical cyclone, such as how the winds extend from the storm center is critical information for emergency management. The spatial structure is also important for new kinetic energy-based metrics for estimating tropical cyclone wind and wave/surge destructive potential [90]. In the future, these new metrics might more accurately characterize large storms like Hurricane Ike, which wreaked havoc well beyond its mere Category 2 status on the Saffir-Simpson Scale. In addition, several studies have made use of QuikSCAT data to examine circulation or vorticity about tropical disturbances [55], to examine various types of cyclone formation [98], and to use more accurate positioning techniques in conjunction with other remote sensing measurements, to better understand the movement and development of the TC from genesis to dissipation [27 and 35]. OSVW interpretation can also be improved when the use of high-resolution wind techniques [95] are employed (Fig. 3 ). These techniques often help overcome some of the sensitivity that the current automated methods have to ambiguous wind direction selection, especially in heavy rain and under poor geometric alignment. Previous techniques [27] required more labor intensive manual techniques to overcome. C-band scatterometers are much less adversely impacted by rain. Ocean vector winds are also useful for improving the accuracy of the environmental winds and the cyclone track forecast.

\subsection{Ocean Model Forcing}

Operationally, a wind forecast is often more useful than an analysis. In this application, satellite winds (vector and scalar) are very useful for improving the accuracy of the initial conditions used to begin the forecast. VW measurements are routinely used to constrain ocean state estimation; in for example, those produced by the Estimating the Circulation and Climate of the Ocean (ECCO) Consortium [121]. Determining spatially and temporally consistent forcing of the ocean on the eddy scale remains a challenge.

\subsection{Currents}

Ocean currents are a combination of geostrophic currents (associated with dynamic height) and Ekman currents associated with surface stress, which are closely related to satellite observations of equivalent neutral winds (e.g. [58 and 59]). Ocean vector winds are critical for determining the Ekman component of the currents. As with other operational applications, all satellite winds, particularly vector winds, contribute to improving forecasts.

\section{SCIENCE TOPICS}

Wind products are used for an enormous range of ocean, atmospheric, and air/sea interaction studies. A bibliography of ocean vector wind studies is available at http://coaps.fsu.edu/scatterometry/bibliography/publicat ions.shtml.

\subsection{Air/Sea Surface Fluxes}

The great importance of winds on fluxes of energy, moisture, momentum, and gases is described by [28]. Wind has the greatest range of relatively high frequency variability of all the observations that contribute to surface fluxes. The changes in wind are linked to changes in other variables such as SST (Sect. 4.4) and atmospheric stability This variability is highly correlated on the atmospheric synoptic scale [P. Hughes, personal communication, 2007], and is likely to be correlated for finer scales (e.g. diurnal). It is important to consider this mutual variability in the calculation of air/sea fluxes. Sufficient sampling to resolve this variability will be important to climate studies and many ocean-modeling applications.

\subsection{High Winds}

High winds play a disproportionately large role in Earth's climate. Mid and high latitude, high wind events (cold air outbreaks) lasting several days, can remove what at typical wind speeds would be a month's worth of the ocean's heat and moisture, leading to the formation of "deep water" that helps drive global ocean circulation patterns. High winds also help exchange disproportionately large amounts of carbon dioxide.

Satellites do not measure 10-minute sustained winds, but rather instantaneous area-averaged winds. One expects 10-minute winds to be more extreme than satellite winds and guidance is required to "translate" scatterometer winds. This is especially true at high wind speeds (winds greater than $20 \mathrm{~m} / \mathrm{s}$ ) that are typically located in tropical cyclones, strong mid-latitude storms, and orographically enhanced regions [96 and 78]. There are questions about how well scatterometers can measure high winds [28], with some results showing 
that scatterometers underestimate high winds [122, 124 and 112]. High wind validation is limited due to the infrequency of such events often located in data-poor remote regions and the questionable measurements of buoys or ships in rough oceans due to wave sheltering. Consequently, most high wind validation and research has been focused on tropical cyclones [100 and 39] and model functions have been developed specifically to obtain higher winds in these storms [123; 24; 1 and 28]. Improved tropical cyclone forecasts have resulted from the availability of scatterometer data [46, 6, 15 and 55] and an increase in hurricane and gale force wind forecasts in mid-latitude storms has resulted from routine use of scatterometer winds by weather forecasters [109 and 20]. Recently, a monthly climatology of the frequency of high winds from QuikSCAT was made available [96].

\subsection{Diurnal Variability}

The diurnal variability of ocean wind can be substantial. It is of interest for ocean forcing (mixing and air/sea heat fluxes) as well as for wind power generation, and can also be linked to variability in cloud cover. Symmetric variability in wind results in a nonsymmetry variability in stress and increases the mean stress. For example, mixing based on diurnal winds (vs. those smoothed over 24 hours) increases the depth of the mixed layer and over a season can lower SSTs by more than $1{ }^{\circ} \mathrm{C}$, and cause increases in the mixed layer salinity [62]. Satellite sampling is currently insufficient for diurnal studies with spatially similar error characteristics, but could improve with better gridding or assimilation techniques and multi-instrument products [36 and 70].

\subsection{Response to SSTs}

Scatterometer observations of surface winds and microwave observations of sea-surface temperature (SST) have revealed that SST exerts a strong influence on surface winds on scales smaller than $\sim 1000 \mathrm{~km}$. Winds are stronger over warm water and weaker over cold water (Fig. 4).

This ocean-atmosphere interaction is clearly evident in the surface winds in operational weather forecast models [73], but is underestimated by about a factor of two because of deficiencies in the parameterization of atmospheric vertical mixing [102]. Observations [68] and mesoscale models with sufficient sensitivity of vertical mixing to stability reveal that the SST influence extends throughout the troposphere in all of the dynamic fields, e.g. the vertical velocity (Fig. 4).
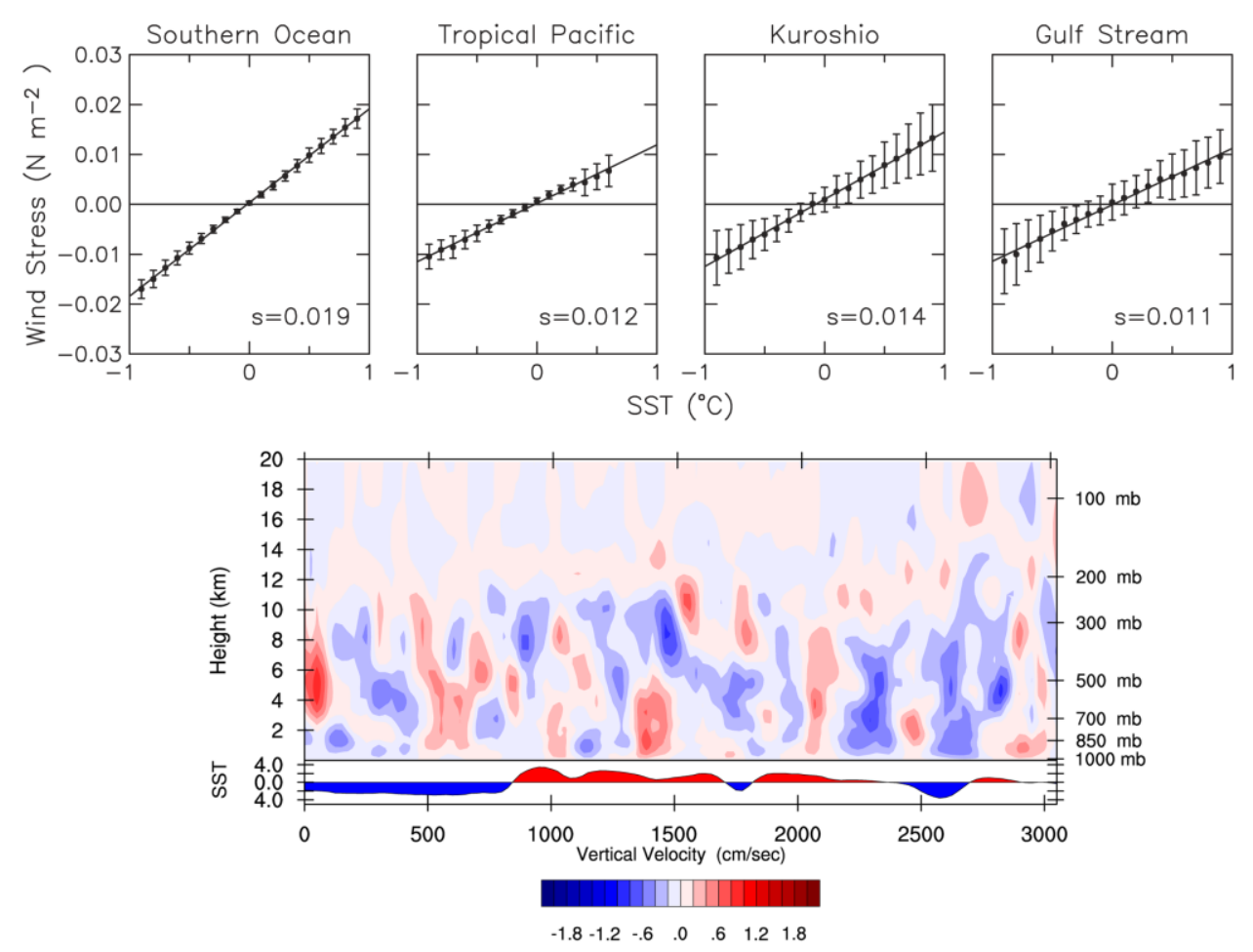

Figure 4. (Upper) Binned scatter plots of small-scale perturbations of wind stress magnitude as a function of SST for four regions of the World Ocean (after [73]). (Lower) The vertical velocity in an east-west section across the Agulhas Return Current region of the South Indian Ocean from a simulation with the Weather Research \& Forecasting model. SST is shown in the bottom panel. The SST influence on tropospheric winds is complex, but can be clearly seen throughout the troposphere (from [102]). 
Because the surface wind response to SST is too weak in the global forecast models, the response of tropospheric winds to SST (Sea Surface Temperature) is also underestimated. Ongoing efforts are utilizing scatterometer data to improve the forecast model responses to SST, both at the surface and in the troposphere.

In regions of tight SST gradients (e.g. near meandering fronts associated with ocean currents), SST-induced perturbations of the wind stress curl develop. Since the wind stress curl drives the large-scale ocean circulation, 2-way coupling (see Sect. 1) between the ocean and atmosphere is expected in these frontal regions. Investigations are underway regarding the feedback effects of SST-induced perturbations of the surface wind stress on the ocean circulation. A study of 2-way ocean-atmosphere coupling in an idealized representation of an eastern boundary current system finds that most of the salient features of eastern boundary currents are either significantly affected by, or the direct result of, these feedback effects [50]. The 2way coupling creates a strong positive wind stress curl within $\sim 100 \mathrm{~km}$ of the coast, weakens the equatorward surface current, strengthens the poleward undercurrent, and reduces the growth rate of baroclinic instability and the magnitude of the eddy kinetic energy.

\subsection{Near Coastal Processes}

Synoptic scale winds are very important for transporting riverine water from coastal shelves to the open ocean [80]. These findings suggest a link between the transport of nutrients and the finfish and shellfish life cycles and population. The upwelling associated with coastal wind variability also appears to be a very important part of the coastal ecosystem (e.g. [45]).

\subsection{Western Boundary Currents}

Western boundary currents have typical widths of about $100 \mathrm{~km}$ with maximum currents of $2-3 \mathrm{~m} / \mathrm{s}$ and SST gradients of about $10^{\circ} \mathrm{C}$ in $200 \mathrm{~km}$. To understand the contribution of these narrow, intense currents to air-sea interaction, the intensification of extratropical storms, and climate variability, is it necessary to resolve these spatial scales in the observations. Therefore, highresolution satellite observations are critical to weather forecasting, climate research, and climate prediction. The measurements that have proved most valuable for studying ocean circulation and air-sea interaction in the WBCs are sea level (from the radar altimeter), wind speed and direction (from the scatterometer), and SST [23].

High-resolution scatterometer winds over the WBCs (Western Boundary Currents) provide convincing evidence that WBCs are affecting the wind structure in the marine boundary layer [77 and 67]. Although the winds are only for $10 \mathrm{~m}$ height, their assimilation into
NWPs is contributing to improved products that are more likely to reveal the details of air-sea interaction over the WBCs, as well as improved forecasts of storms.

\subsection{ENSO and Atlantic Niño}

Ocean surface vector winds are routinely used to forecast ENSO (El Niño/Southern Oscillation) activity and Atlantic Niño [38], both of which are linked to rainfall in South America, and hence linked to river outflow. The depth of the thermocline in the tropical Pacific has been shown to be more accurately modeled when using QuikSCAT rather than NCEP products [49]. One outstanding ENSO-related issue is the source of a systematic discrepancy between QuikSCAT and TAO meridional winds; discrepancies in zonal winds correspond well to ocean currents [57]. Current ocean vector wind coverage is more than sufficient to capture the monthly changes in the wind patterns; however, it is insufficient to capture the strong 12 to 24 hour westerly wind bursts (the average equatorial sampling interval for QuikSCAT, for example, is 18 hours).

\subsection{High Latitude Processes and Water Mass Formation}

High latitudes have remarkably little in situ observations, particularly in the southern hemisphere [93]. In these regions, NWP products are strongly tied to the radiosonde network, with little agreement in the upper atmosphere between NWP products even one grid cell away from the radiosonde observations [59]. Therefore satellite observations of surface data are essential in the high latitudes. The interplay between over-ocean fluxes and over-ice fluxes is a very important part of the high latitude climate [37]. The high latitude fluxes also contribute to deep-water formation [78]. For such events, the very high wind speeds with cold air outbreaks make a very large contribution. Consequently, two outstanding issues for high latitude applications are the need for better temporal sampling and the need for calibration for high wind speeds.

\subsection{Decadal Variability}

ERS and QuikSCAT scatterometers together have collected almost 18 years of vector wind measurements, which greatly facilitate the study of decadal variability. Caution should be applied when using these data sets together: differences in calibration, rain impacts, and sampling cause differences in statistics. Nevertheless, based on scatterometer measurements, [61] identified a near-coherent change of decadal tendency in the wind field over much of the Indo-Pacific region, with the tendency in the 1990s being generally opposite in sign to that in the 2000s. In particular, the Pacific and Indian Ocean trade winds experienced anti-correlated decadal changes. They discussed the implications to the 


\begin{tabular}{|l|l|l|l|l|l|l|}
\hline Name & Heritage & Band(s) & Swath-width & Swath grid & $\begin{array}{l}\text { Launch } \\
\text { date }\end{array}$ & Global access \\
\hline ASCAT Series & Scat & $\mathrm{C}$ & $2 \times 550 \mathrm{~km}$ & $12.5 \mathrm{~km}$ & $\begin{array}{l}2011 \\
2016\end{array}$ & public \\
\hline OceanSat-2 & Scat & $\mathrm{Ku}$ & $1840 \mathrm{~km}$ & $50 \mathrm{~km}$ & 2009 & unknown \\
\hline HY-2 & Scat & $\mathrm{Ku}$ & $1700 \mathrm{~km}$ & $25 \mathrm{~km}$ & 2010 & delayed \\
\hline CFOSAT & Scat & $\mathrm{Ku}$ & $870 \mathrm{~km}$ & $50 \mathrm{~km}$ & 2012 & unknown \\
\hline DFS & Scat, Pass & $\mathrm{Ku}, \mathrm{C}$, Pass & $1800 \mathrm{~km}$ & $\leq 15 \mathrm{~km}$ & 2016 & public \\
\hline XOVWM & Scat, Pol, SAR & $\mathrm{Ku}, \mathrm{C}$, Pol & $1800 \mathrm{~km}$ & $\leq 5 \mathrm{~km}$ & & public \\
\hline Post EPS & Scat & $\mathrm{C}$ & $2 \times 550 \mathrm{~km}$ & $12.5 \mathrm{~km}$ & 2020 & public \\
\hline RADARSAT 1 & SAR & $\mathrm{C}$ & $45-500 \mathrm{~km}$ & $8-100 \mathrm{~m}$ & 1995 & limited \\
\hline RADARSAT 2 & SAR & $\mathrm{C}$ & $45-500 \mathrm{~km}$ & $3-100 \mathrm{~m}$ & 2007 & limited \\
\hline $\begin{array}{l}\text { RADARSAT } \\
\text { Constellation }\end{array}$ & SAR & $\mathrm{C}$ & $45-500 \mathrm{~km}$ & $3-100 \mathrm{~m}$ & 2014 & limited \\
\hline Sentinel-1 & SAR & $\mathrm{C}$ & $400 \mathrm{~km}$ & $40 \mathrm{~m}$ & 2011 & public \\
\hline Tandem-X & SAR & $\mathrm{X}$ & $40 \mathrm{~km}$ & $10 \mathrm{~m}$ & 2009 & limited \\
\hline TerraSAR-X-2 & SAR & $\mathrm{X}$ & $40 \mathrm{~km}$ & $10 \mathrm{~m}$ & 2012 & limited \\
\hline
\end{tabular}

Table 1. Scat is scatterometer, Pass is passive microwave, Pol is passive polarimetric. Public indicates the data are freely available near real time (NRT) and science quality data, delayed indicates delayed mode science quality data, and limited indicates that access will be highly restricted.

meridional and horizontal ocean circulations in relation to the atmospheric teleconnection and oceanic linkages.

\section{FUTURE SATELLITE WIND OBSERVATIONS}

Recent and current satellites are mentioned in Sect. 2. Most of these satellites have been functioning for many years beyond expectations and replacement satellites must be ready soon or the climate quality data record will be broken. Some future satellites are listed below, with more shown in Fig. 5. A timeline of recent, current and future missions is shown in Fig. 5. International access to the data is often highly limited (Tab. 1).

- OceanSat-2 Scatterometer of the Indian Satellite Research Organisation (ISRO);

- HaiYang-2 (HY-2) Scatterometer;

- Chinese-French Oceanographic Satellite (CFOSAT) rotating fan beam scatterometer;

- Extended Ocean Vector Wind Mission (XOVWM) [84; 34 and 48].

- Dual Frequency Scatterometer (DFS) possibly on GCOM-W2

- Post EUMETSAT Polar System (EPS) SCAT

- RADARSAT Constellation

- EU-ESA Global Monitoring for Environment and Security (GMES) Sentinel-1 SAR

- Tandem-X and TerraSAR-X-2 Polarimetric X-band SAR

\section{CONCLUSIONS}

\subsection{Challenges}

The main challenges to satellite ocean wind measurement are (1) availability of data (preferably in near real time), (2) intercalibration of wind (vector and scalar) sensors, (3) insufficient sampling of natural variability (e.g. diurnal and inertial cycles), particularly for vector winds, (4) insufficient resolution and near coastal data for non-SAR instruments, (5) rain contamination (all weather retrievals), and (6) accuracy for high wind speeds $\left(>20 \mathrm{~ms}^{-1}\right)$. Climate studies also require very small calibration drift; otherwise, the challenges are similar for science and operations.

\subsection{Science Requirements for Future Satellite Wind-Sensing Missions}

The observational needs for operational and science activities are similar, except that the science applications would benefit more from better calibration, uniform reprocessing of data as needed, and better archiving of the data. Many operational centers in the southern hemisphere have difficulty working with satellite data transferred in the manner utilized by major weather prediction centers; consequently, they would also benefit from data provided in a common format that is easier to work with and could also be limited to specific regions of interest.

Specific goals quoted from [17] are:

- All-weather retrievals (i.e. accurate retrievals in rain) 
- Accuracy levied upon the selected 10-meter, 1minute sustained wind as defined by operational requirements for a $0-165 \mathrm{kt}$ wind speed range:

○ 5-85 $\mathrm{ms}^{-1}$ : speed $\pm 1 \mathrm{~ms}^{-1}$ and direction \pm 10 degrees ( 2 sigma)

○ 2-5 $\mathrm{ms}^{-1}$ : speed $\pm 1 \mathrm{~ms}^{-1}$ and direction \pm 20 degrees ( 2 sigma)

○ $\quad 0-2 \mathrm{~ms}^{-1}:$ speed $\pm 1 \mathrm{~ms}^{-1}$

- Revisit time interval (defined as the time interval between measurements at a particular point on the ocean surface): every 6 hours (1 to 3 hour goal).

- Reduced product latency: 45-60 minutes from measurement to product availability (15 minute goal)

- $2.5 \mathrm{~km} \times 2.5 \mathrm{~km}$ grid spacing, which is defined as the spacing between unique wind vector retrievals (1 km x $1 \mathrm{~km}$ goal)

- Unique wind vector grid cells to within $2.5 \mathrm{~km}$ of the coast (1 km goal)

- Wind fields delivered into the operational environment

\section{- Product documentation/tutorial/training}

Future OVW (Ocean Vector Wind) measurements need to be sustained and with overlapping periods between sensors to allow for inter-calibration, as per GCOS (Global Climate Observing System) guidelines. Many science activities and most climate activities require a careful study of the influence of rain on $\mathrm{Ku}$ and $\mathrm{C}$-band instruments. The NASA Ocean Vector Wind Science Team has also found that users would benefit from better documentation of derived products, such as regularly gridded fields. Currently there is very little information about the resolution (not grid spacing), smoothing, noise, and inhomogeneity of characteristics for wind or derivative products such as curl. There is also a demand for multi-satellite blended wind/stress products with fine temporal resolution.

For some research activities, a goal for sampling is the resolution of the diurnal and inertial cycles. Note that the sampling goals cannot be achieved with a single satellite in low earth orbit. A constellation of satellites, with freely shared data, is essential to meeting the sampling goals (see Sect. 2.3 and [121]).

The information content of scatterometer winds is grossly underutilized in present NWP models [20 and 102]. Plausibly improved data assimilation could be developed to improve the usage of small-scale information.

The proposed DFS or XOVWM missions are a key component to achieving the intercalibration and time series goals. Recent studies show that a dual frequency scatterometer coupled with a radiometer is extremely effective for a very wide range of conditions. The sampling goals will require a constellation of earth orbiting satellites (CEOS), likely supported by a three or more scatterometers plus satellites with scalar wind measuring instruments. An International Ocean Vector Wind Science Team is being developed to help enhance international collaboration and aid in the calibration of new satellite scatterometers. For very near coastal work, in the short term, SAR best provides the desired information; however, access to SAR data has been quite limited.

\subsection{Timeline and Issue}

\subsubsection{Short Term: 0 to 4 years}

The launch of several new instruments is anticipated within the next few years: three scatterometers (OceanSat2, FY2, and CFOSAT), and two SARs (Tandem-X and TerraSAR-X-2). It is likely that several radiometers and QuikSCAT will fail.

Short-term issues will likely be a lack of continuity in the time series of operationally available Ku-band scatterometer observations, and a lack of intercalibration (for high wind speeds and rain) between wind sensors. The biases between instruments (e.g. C-band vs Ku-band) will limit the scope of decadal variability studies. Rain-related errors in $\mathrm{Ku}$ and $\mathrm{C}$-band scatterometers will remain too poorly understood and characterized for climate studies.

Early in this period, there will be insufficient temporal sampling to study the vector aspects of the evolution of mesoscale features across the globe. If OceanSat2 (launched 23 Sept. 2009) and FY2 are successful missions and their data become available, and if the orbits are chosen to result in good temporal sampling with ASCAT, it will be possible to combine intercalibrated data to globally examine mesoscale variability.

During this period, we anticipate that the assimilation of surface winds in numerical weather prediction models will remain quite useful, although a reduction in sampling may reduce its impact. The observed information below a certain spatial scale will rapidly decay in forecasts. That scale will decrease as the resolution of models improves. For numerical weather prediction centers (such as ECMWF), the loss of QuikSCAT will reduce the impact of scatterometer data on forecast skill. Data from OceanSat-2 or HY2 could compensate for a loss of QuikSCAT if the accuracy of the data is sufficiently good and in case it is shared in near real time.

It is likely that QuikSCAT will be lost within the next few years. For the marine now-casting community and wave community, this will result in an 80 to $90 \%$ loss in detected hurricane force from extratropical cyclones; 
conditions for which many of the challenges mentioned in Sect. 6.1 are relatively important. The impact of QuikSCAT winds on wave forecasting and nowcasting of extratropical storms is so striking that these communities request high priority should be given to replacement of this type of capability. Besides a reduced coverage, to date it is not clear whether a suitable inter-calibration between ASCAT and QuikSCAT would allow for a continuation of the retrievable wind speed range for extreme $(>30 \mathrm{~m} / \mathrm{s})$ winds as available from QuikSCAT. Such intercalibration is very valuable to many climate, science, and operational applications.

\subsubsection{Intermediate Term: 4 to 10 years}

The launching of two new scatterometers (Post-EPS and DFS) is anticipated. It is also highly likely that satellites launched before this period will fail. Additional satellites are likely to be launched near the end of this period. The availability of collocated $\mathrm{Ku}$ and $\mathrm{C}$ band data from DFS, and rain rates from AMSR3 on the same satellite, will allow for climate quality inter-calibration with historical $\mathrm{Ku}$ and $\mathrm{C}$ band radars, enabling climate quality work on a 15 to 20 year time series.

It is anticipated that NWP and reanalysis resolution and parameterizations will increase to the point where surface wind data have a much greater impact, but are still underutilized.

\subsubsection{Long Term: $>10$ years}

It is plausible that air/sea turbulent heat fluxes will simultaneously be determined from satellite, and likely that finer resolution will enable observations closer to land. If the time series of climate quality observations is maintained, and the spatial/temporal sampling is sufficient, the time series will be long enough to investigate a great deal of ocean variability.

\section{REFERENCES}

1. Adams, I. S., W. L. Jones, S. Vasudevan, and S. Soisuvarn, 2005: Hurricane wind retrievals using the SeaWinds scatterometer on QuikSCAT. Proc. of MTS/IEEE OCEANS 2005, Washington, D.C., Marine Technology Society and the Oceanic Engineering Society of the IEEE, 2148-2150.

2. Atlas, R., and R.N. Hoffman, 2000: The use of satellite surface wind data to improve weather analysis and forecasting at the NASA Data Assimilation Office. Satellites, Oceanography and Society, Halpern, D., Elsevier Oceanography Series,

3. Adams, I.S., C.C. Hennon, W. L. Jones, and K. A. Ahmad, 2006: Evaluation of hurricane ocean vector winds from WindSat. IEEE Trans. Geosci. Rem. Sens., 44, $656-667$.
4. Atlas, R. M., R. N. Hoffman, S. C. Bloom, J. C. Jusem, and J. Ardizzone, 1996: A multiyear global surface wind velocity dataset using SSM/I wind observations. Bull. Amer. Meteor. Soc., 77, 869-882.

5. Atlas, R. M., R. N. Hoffman, S. M. Leidner, J. Sienkiewicz, T.-W. Yu, S. C. Bloom, E. Brin, J. Ardizzone, J. Terry, D. Bungato, and J. C. Jusem, 2001: The effects of marine winds from scatterometer data on weather analysis and forecasting. Bull. Amer. Meteor. Soc., 82, 1965-1990.

6. Atlas, R. M., A. Y. Hou, and O. Reale, 2005: Application of SeaWinds scatterometer and TMI$\mathrm{SSM} / \mathrm{I}$ rain rates to hurricane analysis and forecasting. ISPRS Journal of Photogrammetry \& Remote Sensing, 59, 233-243.

7. Atlas, R. M., R. N. Hoffman, J. Ardizzone, S. M. Leidner, and J. C. Jusem, 2008: A new crosscalibrated, multi-satellite ocean surface wind product. Proc. IEEE IGRSS 2008, Boston, MA, I-106-I-109.

8. Attema, E. P., 1991: The active microwave instrument on-board the ERS-1 satellite, Proc. IEEE, 79, 791799.

9. Bettenhausen, M. H., Smith, C. K., Bevilacqua, R. M., Wang, N., Gaiser, P. W., and S. Cox, 2006: A nonlinear optimization algorithm for WindSat wind vector retrievals. IEEE Trans. Geosci. Rem. Sens., 44, 597 610.

10. Bourassa, M. A., 2006, Satellite-based observations of surface turbulent stress during severe weather. Atmosphere - Ocean Interactions, Vol. 2. W. Perrie, Eds., Wessex Institute of Technology Press, pp.35-52.

11. Bourassa, M. A., D. M. Legler, J. J. O'Brien, and S. R. Smith, 2003: SeaWinds validation with research vessels. J. Geophys. Res., 108, 3019, doi:10.1029/2001JC001028.

12. Bourassa, M. A., E. Rodriguez, and R. Gaston. 2009: Summary of the 2008 NASA Ocean Vector Winds Science Team Meeting. BAMS, submitted.

13. Bourassa, M. A., R. Romero, S. R. Smith, and J. J. O’Brien, 2005: A new FSU winds climatology, $J$. Clim., 18, 692-3,704.

14. Brennan, M. J, and R. D. Knabb, 2007: Operational evaluation of QuikSCAT ocean surface vector winds in tropical cyclones at the Tropical Prediction Center/National Hurricane Center. Preprints, 11th Symposium on IOAS-AOLS, San Antonio, TX, AMS. http://ams.confex.com/ams/pdfpapers/117225.

15. Brennan, M.J., C.C. Hennon and R.D. Knabb, 2009: The operational use of QuikSCAT ocean surface vector winds at the National Hurricane Center. Weather and Forecasting, 24, 621-645.

16. Cardone, V. J., H. C. Graber, R. E. Jensen, S. Hasselmann and M.J Caruso, 1995: In search of the true surface wind field during SWADE IOP-1: Ocean wave modeling perspective. The Global AtmosphereOcean System, 3, 107-150. 
17. Chang P. S and Z. Jelenak (eds), 2006: NOAA Operational Satellite Ocean Surface Vector Winds Requirements Workshop Report. NOAA/NESDIS, 52pp. [Available online at

http://manati.orbit.nesdis.noaa.gov/SVW nextgen/SV W_workshop_report final.pdf.]

18. Chang, P.S., Z. Jelenak, J. Sienkiewicz, R. Knabb, and M. Brennan, 2009: Operational utilization and impact of satellite remotely-sensed ocean surface vector winds in the marine warning and forecasting environment, Oceanography Magazine, 22, 194-207.

19. Chelton D. B., M. G. Schlax, M. H. Freilich, and R. F. Milliff, 2004: Satellite measurements reveal persistent small-scale features in ocean winds. Science, $\mathbf{3 0 3}$, 978-983, doi:10.1126/science.1091901.

20. Chelton, D. B., M. H. Freilich, J. M. Sienkiewicz, and J. M. Von Ahn, 2006: On the use of QuikSCAT scatterometer measurements of surface winds for marine weather prediction. Mon. Wea. Rev., 134, 2055-2071.

21. Cornillon, P., and K. A. Park, 2001: Warm core ring velocities inferred from NSCAT, Geophys. Res. Lett., $28,575-578$.

22. Cox, A. T. and V. R. Swail, 2001: A global wave hindcast over the period 1958-1997: validation and climate assessment. J. Geophys. Res., 106, C2, 23132329.

23. Cronin, M. \& Co-Authors (2010). "Monitoring Ocean Atmosphere Interactions in Western Boundary Current Extensions" in these proceedings (Vol. 2), doi:10.5270/OceanObs09.cwp.20

24. Draper, D. W. and D. G. Long, 2004a: Simultaneous wind and rain retrieval using SeaWinds data. IEEE Trans. Geosci. Rem. Sens., 42, 1411-1423.

25. Draper, D. W., and D. G. Long, 2004b: Evaluating the effect of rain on SeaWinds scatterometer measurements, J. Geophys. Res., 109, C02005, doi:10.1029/2002JC001741.

26. Ebuchi, N., H. C. Graber, and M. J. Caruso, 2002: Evaluation of wind vectors observed by QuikSCAT/SeaWinds using ocean buoy data, $J$. Atmos. Oceanic Technol., 19, 2049-2062.

27. Edson, R. T., M. A. Lander, C.E. Cantrell, J. L. Franklin, J. D. Hawkins, and P. S. Chang, 2002: Operational use of QuikSCAT over tropical cyclones. The $25^{\text {th }}$ Conference on Hurr. and Trop. Met., San Diego, CA, AMS, 41-42.

28. Fairall, C. \& Co-Authors (2010). "Observations to Quantify Air-Sea Fluxes and their Role in Climate Variability and Predictability" in these proceedings (Vol. 2), doi:10.5270/OceanObs09.cwp.27

29. Fernandez, D. E., J. Carswell, S. Frasier, P. S. Chang, P. G. Black, and F. D. Marks, 2006: Dual-polarized C and $\mathrm{Ku}$-Band ocean backscatter response to hurricane force winds. J. Geophys. Res., 11, C08013, doi:10.1029/2005JC003048.
30. Figa-Saldaña J, J. J. W. Wilson, E. Attema, R. Gelsthorpe, M. R. Drinkwater, and A. Stoffelen, 2002: The Advanced Scatterometer (ASCAT) on the Meteorological Operational (MetOp) platform: A Follow-on for European wind scatterometers, Canadian J. of Rem. Sens., 28, 404-412.

31. Freilich, M. H., 1997: Validation of vector magnitude datasets: effects of random component errors, $J$. Atmos. Oceanic Technol., 14, 695-703.

32. Freilich, M. H. and B. A. Vanhoff, 2006: The accuracy of preliminary WindSat vector wind measurements: comparisons with NDBC buoys and QuikSCAT. IEEE Trans. Geosci. Rem. Sens., 44, 622-637.

33. Gaiser, P. W., K. M. St. Germain, E. M. Twarog, G. A. Poe, W. Purdy, D. Richardson, W. Grossman, W. L. Jones, D. Spencer, G. Golba, J. Cleveland, L. Choy, R. M. Bevilacqua, and P. Chang, 2004: The WindSat spaceborne polarimetric microwave radiometer: Sensor description and early orbit performance. IEEE Trans. Geosci. Rem. Sens., 42, 2347-2361.

34. Gaston, R. and E. Rodrìguez, 2008: Quikscat follow-on concept study. Tech. Rep. JPL Publication 08-18, Jet Propulsion Laboratory, http://winds.jpl.nasa.gov/publications/QFO MissionC onceptReport_JPL_08-18_2.pdf.

35. Gierach, M. M., M. A. Bourassa, P. Cunningham, J. J. O'Brien, and P. D. Reasor, 2007: Vorticity-based detection of tropical cyclogenesis. J. Appl. Meteor. Climatol., 46, 1214-1229, doi:10.1175/JAM2522.1.

36. Gille, S. T., S. G. Llewellyn Smith, and N. M. Statom, 2005: Global observations of the land breeze. Geophys. Res. Lett., 32, L05605, doi:10.1029/2004GL022139.

37. Gille, S. \& Co-Authors (2010). "Surface Fluxes in High Latitude Regions" in these proceedings (Annex), doi:10.5270/OceanObs09.

38. Han W., P. J. Webster, J. Lin, W. T. Liu, R. Fu, D. Yuan and $\mathrm{A}$. $\mathrm{Hu}, 2008$ : Dynamics of intraseasonal sea level and thermocline variability in the equatorial Atlantic during 2002-03. J. Phys. Oceanogr., 38, 945-967, doi:10.1175/2008JPO3854.1.

39. Hennon, C. C., D. G. Long, and F. J. Wentz, 2006: Validation of QuikScat wind retrievals in tropical cyclone environments. 27th Conf. on Hurr. and Trop. Met., Monterey, CA, AMS, JP1.1.

40. Hilburn, K. A. and F. J. Wentz, 2008: Intercalibrated passive microwave rain products from the Unified Microwave Ocean Retrieval Algorithm (UMORA). $J$. Appl. Meteor. Climatol., 47, 778-794.

41. Hilburn, K. A., M. A. Bourassa and J. J. O'Brien, 2003: Scatterometer-derived research-quality surface pressure fields for the Southern Ocean. J. Geophys. Res., 108, 10.1029/2003JC001772.

42. Horstmann, J., W. Koch, S. Lehner and R. Tonboe. 2000: Wind retrieval over the ocean using synthetic aperture radar with $\mathrm{C}$-band $\mathrm{HH}$ polarization. IEEE Trans. Geosci. Rem. Sens., 38, 2122-2131. 
43. Horstmann, J., H. Schiller, J. Schulz-Stellenfleth, and S. Lehner, 2003: Global wind retrieval from SAR. IEEE Trans. Geosci. Rem. Sens., 41, 2277-2286.

44. Horstmann, J., D. R. Thompson, F. Monaldo, S. Iris, and H. C. Graber, 2005: Can synthetic aperture radars be used to estimate hurricane force winds? Geophys. Res. Lett., 32, L22801, doi:10.1029/2005GL023992.

45. Hu, H., and W. T. Liu, 2003: Oceanic thermal and biological responses in Santa Ana Winds. Geophys. Res. Lett., 30, 1596, doi:10.1029/2003GL017208.

46. Isaksen, L., and A. Stoffelen, 2000: ERS-Scatterometer wind data impact on ECMWF's tropical cyclone forecasts. IEEE Trans. Geosci. Rem. Sens., 38, 18851892.

47. Isaksen, L., and P. A. E. M. Janssen, 2004: The benefit of ERS Scatterometer Winds in ECMWF's variational assimilation system. Quart. J. Roy. Meteor. Soc., 130, 793-1,814

48. Jelenak, Z. and P. Chang, 2008: NOAA Operational Satellite Ocean Surface Vector Winds QuikSCAT Follow-on Mission: User Impact Study Report, 91 pp. http://manati.orbit.nesdis.noaa.gov/SVW_nextgen/QF $\underline{\mathrm{O} \text { user impact study final.pdf }}$

49. Jiang, C., L. Thompson, and K. A. Kelly, 2008: Equatorial influence of QuikSCAT winds in an isopycnal ocean model compared to NCEP2 winds, Ocean Modelling, 24, 65-71.

50. Jin, Xin, Changming Dong, Jaison Kurian, James C. McWilliams, Dudley B. Chelton, Zhijin Li, 2009: SST-Wind Interaction in Coastal Upwelling: Oceanic Simulation with Empirical Coupling. J. Phys. Oceanogr., 39, 2957-2970. doi:10.1175/2009JPO4205.1.

51. Johnson, J., L. Williams, E. Bracalente, F. Beck, and W. Grantham, 1980: SEASAT-A satellite scatterometer instrument evaluation. IEEE J. Ocean. Eng., OE-5, $138-144$

52. Josey, S. A., E. C. Kent and P. K. Taylor, 1999: New insights into the ocean heat budget closure problem from analysis of the soc air-sea flux climatology. Journal of Climate, 12, 2856-2880.

53. Kara, A. B., J. Metzger, and M. A. Bourassa, 2007: Ocean current and wave effects on wind stress drag coefficient and fluxes over the global ocean. Geophys. Res. Letts., 34, L01604, doi:10.1029/2006GL027849.

54. Kara, A. B., A. J. Wallcraft, and M. A. Bourassa, 2008: Air-sea stability effects on the $10 \mathrm{~m}$ winds over the global ocean: Evaluations of air-sea flux algorithms. $J$. Geophys. Res., 113, C04009, doi:10.1029/2007JC004324.

55. Katsaros, K. B., E. B. Forde, P. Chang, and W. T. Liu, 2001: QuikSCAT's SeaWinds facilitates early identification of tropical depressions in 1999 hurricane season. Geophys. Res. Lett., 28, 1043-1046.

56. Kelly, K. A., S. Dickinson, M. J. McPhaden, and G. C. Johnson, 2001: Ocean currents evident in satellite wind data. Geophys. Res. Lett., 28, 2469-2472.
57. Kelly, K. A., Dickinson, S., and G. C. Johnson, 2005: Scatterometer winds at TAO buoys reveal timevarying surface currents for the tropical Pacific Ocean, J. Atmos. Ocean. Tech. 22, 735-745.

58. Lagerloef, G., R. Lukas, F. Bonjean, J. Gunn, G. Mitchum, M. Bourassa, and T. Busalacchi, 2003: El Niño tropical Pacific Ocean surface current and temperature evolution in 2002 and outlook for early 2003. Geophys. Res. Lett., 30, 1514, doi:10.1029/2003GL017096.

59. Lagerloef, G. \& Co-Authors (2010). "Resolving the Global Surface Salinity Field and Variations by Blending Satellite and In Situ Observations" in these proceedings (Vol. 2), doi:10.5270/OceanObs09.cwp.51

60. Langland, R.H., R. N. Maue and C. H. Bishop, 2008: Uncertainty in atmospheric temperature analysis. Tellus A, 60, 598-603.

61. Lee, T., and M. J. McPhaden 2008: Decadal phase change in large-scale sea level and winds in the IndoPacific region at the end of the $20^{\text {th }}$ century. Geophys. Res. Lett., 35, L01605, doi:10.1029/2007GL032419.

62. Lee, T., O. Wang, W.-Q. Tang, and W. T. Liu, 2008: Wind stress measurements from the QuikSCATSeaWinds scatterometer tandem mission and the impact on an ocean model. J. Geophys. Res., 113, C12019, doi:10.1029/2008JC004855.

63. Leslie, L. M., B. W. Buckley, and M. Leplastrier. 2008: The operational impact of QuikSCAT winds in Perth, Australia: examples and limitations. Wea. Forecast., 23, 183-193.

64. Liu, W. T., 2002: Progress in scatterometer application. J. Oceanogr., 58, 121-136.

65. Liu, W. T. and W. Tang, 1996: Equivalent Neutral Wind. JPL Publication 96-17, Jet Propulsion Laboratory, Pasadena, 16 pp.

66. Liu, W. T., and X. Xie, 2006: Measuring ocean surface wind from space. Remote Sensing of the Marine Environment, Manual of Remote Sensing, Third Edition, Vol. 6, , J. Gower, Ed., Amer. Soc. for Photogrammetry and Remote Sens., pp. 149-178.

67. Liu, W. T. and X. Xie, 2008: Ocean-atmosphere momentum coupling in the Kuroshio Extension observed from space. J. Oceanogr., 64, 631-637.

68. Liu, W. T., X. Xie, and P. P. Niiler, 2007: Oceanatmosphere interaction over Agulhas extension meanders. J. Climate, 20, 5784-5797.

69. Liu, W. T., W. Tang, and X. Xie, 2008a: Windpower distribution over global ocean. Geophys. Res. Lett., 35, L13808, doi:10.1029/2008GL034172.

70. Liu, W. T., W. Tang, X. Xie, R. Navalgund, and K. Xu, 2008b: Power density of ocean surface wind-stress from International scatterometer tandem missions. Int. J. Remote Sens., 29, 6109-6116. 
71. Long, D.G., 2002: High resolution wind retrieval from SeaWinds, Proc. of IGRSS '02, Toronto, Canada, IEEE, 751-753.

72. Long, D.G., 2004: Reconstruction of high resolution ocean wind vectors from low resolution scatterometer measurements. Proc. of SPIE vol. 5562 Image Reconstruction from Incomplete Data III, Bellingham, WA, SPIE, 196-207.

73. Maloney, E. D., and D. B. Chelton, 2006: An assessment of the sea surface temperature influence on surface wind stress in numerical weather prediction and climate models. J. Clim., 19, 2743-2762.

74. Mears, C. A., D. K. Smith, and F. J. Wentz, 2001: Comparison of special sensor microwave imager and buoy-measured wind speeds from 1987 - 1997. J. Geophys. Res., 106, 11719-11729.

75. Meissner, T. and F. J. Wentz, 2009: Wind vector retrievals under rain with passive satellite microwave radiometers. IEEE Trans. Geosci. Rem. Sens., In press.

76. Meissner, T., D. K. Smith, and F. J. Wentz, 2001: A 10year intercomparison between collocated special sensor microwave imager oceanic surface wind speed retrievals and global analyses. J. Geophys. Res., 106, 11731-11742.

77. Minobe, S., A. Kuwano-Yoshida, N. Komori, S.-P. Xie, and R. J. Small, 2008: Influence of the Gulf Stream on the troposphere. Nature, 452, 206-209.

78. Moore, G. W. K. and I. A. Renfrew, 2005: Tip jets and barrier winds: a QuikSCAT climatology of high wind speed events around Greenland. J. Clim., 18, 37133725 .

79. Morey, S. L., S. R. Baig, M. A. Bourassa, D. S. Dukhovskoy, and J. J. O'Brien, 2006: Remote forcing contribution to storm-induced sea level rise during Hurricane Dennis, Geophys. Res. Lett., 33, L19603, doi:10.1029/2006GL027021.

80. Morey, S. L., D. S. Dukhovskoy, and M. A. Bourassa, 2009: Connectivity between variability of the Apalachicola River flow and the biophysical oceanic properties of the northern West Florida Shelf. Continental Shelf Research, Volume 29, Issue 9, 15 May 2009, Pages 1264-1275, doi:10.1016/i.csr.2009.02.003.

81. Naderi, F., M. H. Freilich, and D. G. Long, 1991: Spaceborne radar measurement of wind velocity over the ocean: an overview of the NSCAT scatterometer system. Proc. of the IEEE, 850-866.

82. Nie, C., and D. G. Long, 2008a: A C-band scatterometer simultaneous wind/rain retrieval method, IEEE Trans. Geosci. Rem. Sens., 46, 3618-3632.

83. Nie, C., and D. G. Long, 2008b: RADARSAT ScanSAR wind retrieval and rain effects on ScanSAR measurements under hurricane conditions. Proc. of IGRSS'08, Boston, MA, IEEE, 493-496.
84. NRC, 2007: Options to Ensure the Climate Record from the NPOESS and GOES-R Spacecraft: A Workshop Report. 84pp. http://www.nap.edu/catalog.php?record_id=12033\#toc

85. Owen, M. P., and D. G. Long, 2009: Land contamination compensation for QuikSCAT nearcoastal wind retrieval. IEEE Trans. Geosci. Rem. Sens., 47, 839-850.

86. Perrie, W., W. Zhang, M. Bourassa, H. Shen, and P. W. Vachon, 2008: Impact of satellite winds on marine wind simulations. Wea. Forecast., 23, 290-303.

87. Portabella, M., and A. Stoffelen, 2006: Scatterometer backscatter uncertainty Due to wind variability. IEEE Trans. Geosci. Rem. Sens., 44, 3356-3362.

88. Portabella, M., and A. Stoffelen, 2009: On scatterometer ocean stress. J. Atmos. Ocean. Techn., 26, 368-382.

89. Portabella, M., A. Stoffelen, and J. A. Johannessen, 2002: Toward an optimal inversion method for SAR wind retrieval. J. Geophys. Res., 107, doi:10.1029/2001JC000925.

90. Powell, M. D., and T. A. Reinhold, 2007: Tropical cyclone destructive potential by integrated kinetic energy. Bull. Amer. Meteor. Soc., 87, 513-526.

91. Quilfen, Y., C. Prigent, B. Chapron, A. A. Mouche, and N. Houti, 2007: The potential of QuikSCAT and WindSat observations for the estimation of sea surface wind vector under severe weather conditions. $J$. Geophys. Res., 112, C09023, doi:10.1029/2007JC004163.

92. Rienecker, M. \& Co-Authors (2010). "Synthesis and Assimilation Systems - Essential Adjuncts to the Global Ocean Observing System" in these proceedings (Vol. 1), doi:10.5270/OceanObs09.pp.31

93. Risien, C. M., and D. B. Chelton, 2008: A Global Climatology of Surface Wind and Wind Stress Fields from Eight Years of QuikSCAT Scatterometer Data. J. of Phys. Oceanog., 38, 2379-2413.

94. Ross, D.B., V.J. Cardone, J. Overland, R. D. McPherson, W. J. Pierson Jr., and T. Yu, 1985: Oceanic surface winds. Adv. Geophys., 27, 101-138.

95. Said, F., and D.G. Long, 2008: Effectiveness of QuikSCAT's ultra high resolution images in determining tropical storm eye location. Proc. of IGRSS'08, Boston, MA, IEEE, 351-354.

96. Sampe, T. and S.-P. Xie, 2007: Mapping high sea winds from space. Bull. Amer. Meteor. Soc., 88, 1965-1978.

97. Schlax, M. G., D. B. Chelton and M. H. Freilich, 2001: Sampling errors in wind fields constructed from single and tandem scatterometer datasets. J. Atmos. Oceanic Tech., 18, 1014-1036.

98. Sharp, R. J., M. A. Bourassa, and J. J. O'Brien, 2002: Early detection of tropical cyclones using SeaWindsderived vorticity. Bull. Amer. Meteor. Soc., 83, 879889. 
99. Shen, H., W. Perrie and Y. He, 2007: On SAR hurricane wind speed ambiguities. Proc. of IGARSS'07, IEEE, 2531-2534.

100. Smith, D., C. Mears, C. Gentemann, and F. Wentz, 2000: Validation of QuikSCAT tropical cyclone winds. 24th Conf. on Hurr. and Trop. Met., Boston, MA, AMS, 193-194.

101. Smith, S. R., J. Servain, D. M. Legler, J. N. Stricherz, M. A. Bourassa, and J. J. O'Brien, 2004: In situ based pseudo-wind stress products for the tropical oceans. Bull. Amer. Meteor. Soc., 85, 979-994.

102. Song, Q., D. B. Chelton, S. K. Esbensen, N. Thum and L. W. O'Neill, 2009: Coupling between sea-surface temperature and low-level winds in mesoscale numerical models. J. Clim., 22, 146-164.

103. Spencer, M. W., C. Wu, and D. G. Long, 2000: Improved resolution backscatter measurements with the SeaWinds pencil-beam scatterometer. IEEE Trans. Geosci. Rem. Sens., 38, 89-104.

104. Stoffelen, A., 1998: Towards the true near-surface wind speed: error modelling and calibration using triple collocation. J. Geophys. Res., 103, 7755-7766.

105. Swail, V. \& Co-Authors (2010). "Wave Measurements, Needs and Developments for the Next Decade" in these proceedings (Vol. 2), doi:10.5270/OceanObs09.cwp.87

106. Tsai, W-Y, J. E. Graf, C. Winn, J. N. Huddleston, S. Dunbar, M. H. Freilich, F. J. Wentz, D. G. Long, and W. L. Jones, 1999: Postlaunch Sensor Verification and Calibration of the NASA Scatterometer. IEEE Trans. Geosci. Remote Sens., 37, 1517-1542.

107. Vachon, P. W. and F. W. Dobson, 1996: Validation of wind vector retrieval from ERS-1 SAR images over the ocean. Global Atmos. Ocean Syst., 5, 177-187.

108. Vogelzang, Jur, Ad Stoffelen, Anton Verhoef, John de Vries, Hans Bonekamp, 2009: Validation of TwoDimensional Variational Ambiguity Removal on SeaWinds Scatterometer Data. J. Atmos. Oceanic Technol., 26, 1229-1245. doi:10.1175/2008JTECHA1232.1.

109. Von Ahn, J., J.M. Sienkiewicz and P. Chang, 2006: Operational impact of QuikSCAT winds at the NOAA ocean prediction center. Wea. Forecast., 21, 523-539.

110. Wackerman, C., C. Rufenach, R. Schuchman, J. Johannessen, and K. Davidson, 1996: Wind vector retrieval using ERS-1 synthetic aperture radar imagery. IEEE Trans. Geosci. Rem. Sens., 34, 13431352.

111. Weissman, D. E., K. L. Davidson, R. A. Brown, C. A. Friehe, and F. Li, 1994: The relationship between the microwave radar cross section and both wind speed and stress: Model function studies using Frontal AirSea Interaction Experiment data. J. Geophys. Res., 99, C5, doi:10.1029/93JC03371.
112. Weissman, D.E., M. A. Bourassa, and J. Tongue, 2002: Effects of rain rate and wind magnitude on Sea Winds scatterometer wind speed errors. J. Atmos. Ocean. Technol., 19, 738-746.

113. Wentz, F.J., 1992. Measurement of Oceanic Wind Vector Using Satellite Microwave Radiometers, IEEE Trans. Geosci. Rem. Sens., 30, 960-972.

114. Wentz, F.J., 1997. A well-calibrated ocean algorithm for Special Sensor Microwave/Imager. J. Geophys. Res., 102, 8703-8718.

115. Wentz, F.J, and D.K. Smith, 1999: A model function for the ocean normalized radar cross-section at $14 \mathrm{GHz}$ derived from NSCAT observations. J. Geophys., Res., 104, 11499-11524.

116. Wentz, F. J., L. Ricciardulli, K. A. Hilburn, and C. A. Mears, 2007: How much more rain will global warming bring? Science, 317, 233-235.

117. Williams, B. A., and D. G. Long, 2008a: Estimation of hurricane winds from SeaWinds at ultra high resolution. IEEE Trans. Geosci. Rem. Sens., 46, 29242935.

118. Williams, B. A., and D. G. Long, 2008b: Rain and wind estimation from SeaWinds in hurricanes at ultra high resolution. Proc. of IGRSS'08, Boston, MA, IEEE, 664-667.

119. Wilson, S. \& Co-Authors (2010). "The Ocean Surface Topography Constellation: The Next 15 Years in Satellite Altimetry" in these proceedings (Vol. 2), doi:10.5270/OceanObs09.cwp.92.

120. Woiceshyn, P. M., M. G. Wurtele, and G. F. Cunningham, 1989: Wave hindcasts forced by scatterometer and other wind fields, $2^{\text {nd }}$ Int. Workshop on Wave Hindcast. and Forecast., 268-277.

121. Wunsch, C. and P. Heimbach, 2007: Practical global oceanic state estimation. Physica D-Nonlinear Phen., 230, 197-208.

122. Yuan, X., 2004: High-wind-speed evaluation in the Southern Ocean. J. Geophys. Res., 109, D13101, doi:10.1029/2003JD004179.

123. Yueh, S. H., B. W. Stiles, and W. T. Liu, 2003: QuikSCAT wind retrievals for tropical cyclones. IEEE Trans. Geosci. Rem. Sens., 41, 2616-2628.

124. Zeng, L. and R. A. Brown, 1998: Scatterometer observations at high wind speeds. J. Appl. Meteor., 37, $1412-1420$

125. Zhang, H.-M., J. J. Bates, and R. W. Reynolds, 2006a: Assessment of Composite Global Sampling: Sea Surface Wind Speed. Geophys. Res. Lett., 33, L17714, doi:10.1029/2006GL027086.

126. Zhang, H.-M., R. W. Reynolds, and J. J. Bates, 2006b: Blended and gridded high resolution global sea surface wind speed and climatology from multiple satellites: 1987 - present. 2006 Annual Meeting, Atlanta, GA, AMS, P2.23. 